\title{
The State of the Art of Agricultural Research on Maize Crop in Mozambique
}

\author{
Sérgio Feliciano Come \\ Lecturer at Universidade Zambeze, Mozambique. Ph.D. in Rural Extension by Universidade \\ Federal de Viçosa, Brazil. Corresponding author. E-mail: sergiofcome@gmail.com
}

\section{José Ambrósio Ferreira Neto}

Lecturer at Universidade Federal de Viçosa, Brazil. Ph.D. in Development, Agriculture and Society by Universidade Federal Rural do Rio de Janeiro, Brazil. E-mail: ambrosioufv@gmail.com

\section{Eunice Paula Armando Cavane}

Lecturer at Universidade Eduardo Mondlane, Mozambique. Ph.D. in Rural Extension by Michigan State University, United States of America. E-mail: cavaneeu@gmail.com

Received: Sep. 3, 2020

doi:10.5296/jas.v8i4.17615
Accepted: Oct. 9, 2020

Published: Oct. 15, 2020

URL: https://doi.org/10.5296/jas.v8i4.17615

\begin{abstract}
This study mapped the agricultural researches on maize crop in Mozambique. A bibliographic research in the internet was carried out. Thus, we selected 72 studies related to maize crop in Mozambique. Descriptive statistics was used to group the studies according to year of publication and region that they cover. The main themes of the studies were grouped based on Commodity System Approach (CSA). The results point out that the scientific production on maize has relatively increased since 2011. 29\% of studies address maize crop in entire country while $26 \%$ include other countries, mainly those neighbors of Mozambique. At the provincial level, Manica with 14\%, Maputo with $7 \%$ and Tete with $7 \%$ are the provinces with relative high percentage of studies. Therefore, there is not relationship between the percentage of studies and the agricultural potential of the provinces in the country. The main themes of scientific production on maize are agronomic techniques for maize production $(50 \%)$ and maize market issues $(22 \%)$. Although post-harvest losses of maize are significant in Mozambique, only $2.8 \%$ of the studies analyzed this theme. Recently, some research on maize crop address transversal issues as environment, gender and nutrition. But the
\end{abstract}


percentage of studies analyzing these themes is still low. Future studies are suggested to address themes linking transversal issues and maize crop. Maize storage and its market are other themes that deserve to be studied in the future.

Keywords: agriculture, agricultural market, maize farming, scientific production

\section{Introduction}

The majority of the population of Sub-Saharan Africa (SSA) lives in rural areas where poverty is high. Thus, as almost all of SSA rural households depend on agriculture, and given the sector's great contribution to the economy as a whole, this activity is a key sector in the region's economic development (Christiaensen, 2017). In SSA, agriculture contributes with $30 \%$ of the Gross Domestic Product, $30 \%$ of exports and employs about $75 \%$ of people (Wakhungu, 2010).

Among the most agricultural crops practiced in SSA, maize stands out, as it is the main staple food in many SAA countries (Byerlee and Heisey, 1996). Maize represents about 32\% of calorie intake in the southern and eastern regions of the African continent, reaching over $50 \%$ in countries like Zambia, Malawi and Lesotho (Cairns et al. 2012).

In Mozambique, maize is the most important crop in terms of number of farmers growing it and in terms of area dedicated to grow it. According to MASA (2015), in 2015, maize crop was cultivated by $72.5 \%$ of household's farmers in Mozambique and occupied more than $30 \%$ of cultivated area in the country. Given the relevance of this cereal, the increase of maize production and its yield are crucial for achieving food security in Mozambique (Cavane and Donovan, 2011). The agricultural research sector has placed maize as one of the priority crops on its research agenda (Walker et al. 2006). Despite the priority given to research on maize, the yield of this crop (1.2 ton/ha) remains lower than its potential. According to IIAM and FAEF (2010), the potential of maize yield in Mozambique is between 5-8 (ton/ha). It means that actually maize yield in Mozambique is about $15 \%-24 \%$ of its potential.

It takes about 15 years since maize has been elected to be priority in agricultural research agenda. However, there are few studies analyzing the state of art on maize crop in Mozambique. Thus, this article aims to map the aspects that are being highlighted in agricultural research on maize crop in Mozambique. The paper has potential to illustrate if the main themes that are researched are linked to main problems associated with maize crop in the country. It will also highlight the gaps of the current research on maize crop. The results may be used to guide future researches on maize crop in Mozambique in the main aspects that are currently less studied.

\section{Methodological Procedures}

This study is a state of art. This type of study, also called bibliographic research, is the set of cultural or scientific contributions made on a given subject (Lakatos and Marconi, 2001). In this work, we did the search for the bibliography in two main moments. Initially, we inserted into electronic sites as Google, Google scholar, the keywords "milho", "Moçambique", 


\section{Mll Macrothink}

Journal of Agricultural Studies

ISSN 2166-0379

2020, Vol. 8, No. 4

"pesquisa" and "agricultura" (in Portuguese). In the second and last moment, we repeated introducing the same words translated into English: "maize", "Mozambique", "research" and "agriculture" in the same electronic sites. The search of studies was done in August, 2019.

By reading the titles, 187 works were pre-selected. After that, we read the titles and the abstracts. At that moment, 78 papers were excluded because some of these studies were repeated and others were not research on maize crop in Mozambique. Therefore, 109 studies remained in this phase. This was followed by the selection of studies classified as articles published in scientific journals with ISSN, those presented at scientific events and later published in books with ISBN or ISSN, working papers with ISBN/ISSN and doctoral thesis. This exercise resulted in the selection of 72 studies. Of the 72 selected studies, 52 are papers published in journals, 11 papers presented at scientific events, five working papers and four doctoral thesis. The selected scientific production was analyzed using Bardin's content analysis technique. In this technique, the researcher seeks to understand the characteristics, structures or models that are in the messages of the study material (Godoy, 1995). According to the author, this technique can be applied in different speeches and to all forms of communication. Content analysis has three phases, namely: pre-analysis, material exploration and the treatment and interpretation of results (Bardin, 2011).

In the present study, the pre-analysis consisted of reading the titles and abstracts of the works resulting from the electronic search. This exercise allowed the selection of scientific production that addresses maize crop in Mozambique. In the material exploration phase, we read the abstracts and the conclusions or final considerations of the 72 selected works. After that, the selected studies were grouped according to year of publication, the region covered and the main themes.

The definition of the main research theme constituted the phase of treatment and interpretation of the results. The themes were defined based on the Commodity System Approach (CSA). According to Freitas et al. (2011), the CSA is a flow that begins with the input market and ends with the consumer, including institutions that can influence production process. Therefore, the themes of the scientific production were defined according to the phases through which the maize goes, from the agricultural input market to the final consumer.

\section{Results and Discussion}

\subsection{Annual Evolution of Scientific Production on Maize in Mozambique}

A relevant issue when making a state of the art is to analyze the quantity of studies along the time. Based on the search criteria used in this study, the first research on maize crop in Mozambique is from 1988 (Figure 1). However, until 2010, the number of publications remained below four per year. During that period, excluding the years that did not have studies on maize, it was published an average of 1.86 papers per year. 


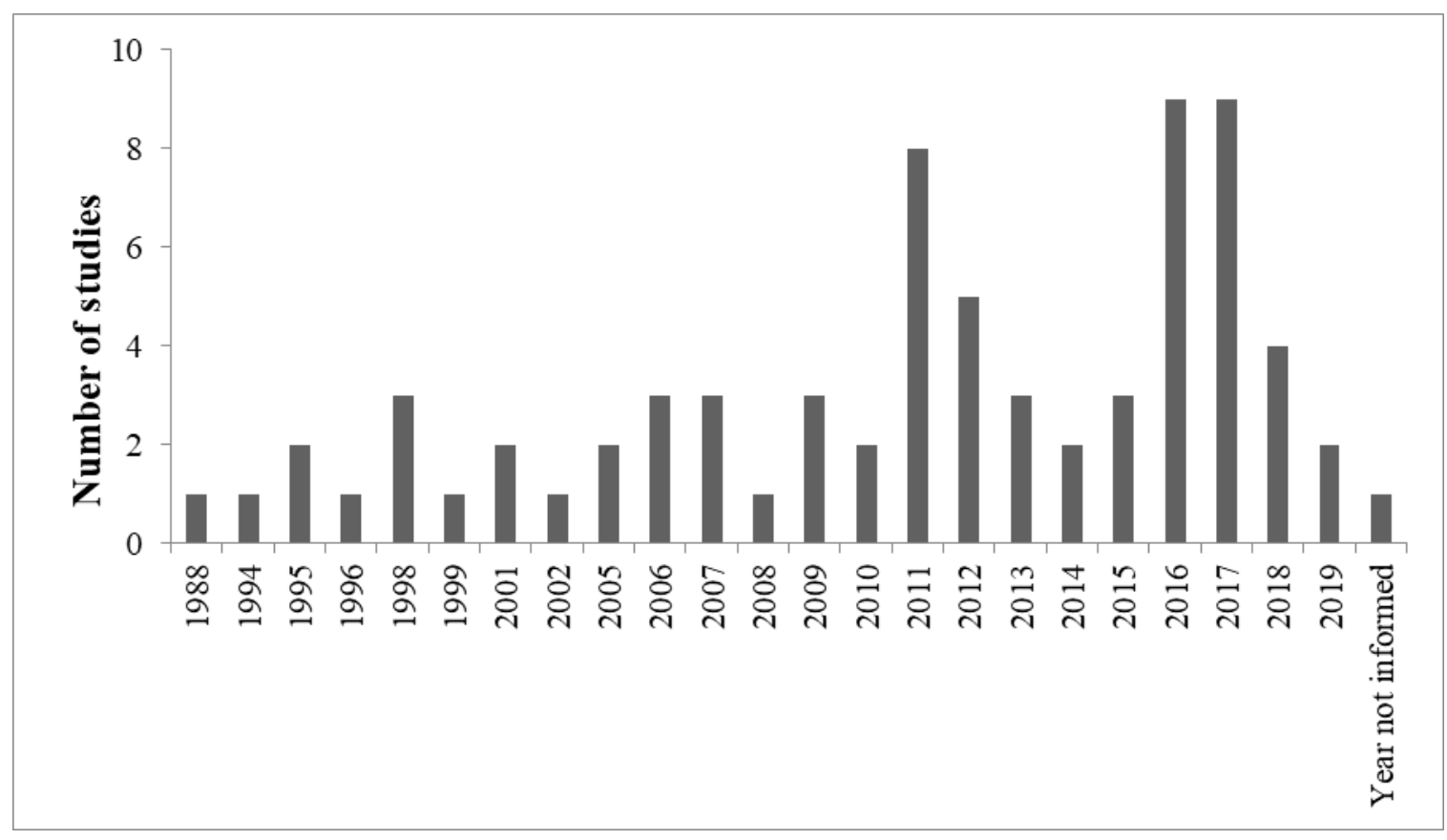

Figure 1. Annual evolution of studies on maize in Mozambique (1988-2019)

Source: Authors. Some years were not included because they did not have publications.

The reduced scientific production before 2011 is explained by three main factors. The first is related to the country's historical and political trajectory. After independence in 1975, Mozambique had not agricultural researchers to carry out relevant studies. To make matters worse, between 1976 and 1992 there was a Civil War which consequences significantly impacted the development of the country, also regarding agricultural research. For example, many infrastructures of the Agricultural Research Institute of Mozambique (Instituto de Investigação Agrária de Moçambique-IIAM), the largest agricultural research institution in the country, were destroyed during the war (Flaherty et al. 2010). Besides it, the war limited greatly international organizations and researchers to do agricultural researches in Mozambique.

The second factor is the fact that, compared to other countries in southern and eastern Africa, Mozambique began very late to offer scientific training (Sitoe, 2014). It was about 20 years ago that, through Universidade Eduardo Mondlane (UEM), the oldest higher education institution in Mozambique, the country started offering master's programs in agricultural sciences. Although UEM began offering undergraduate program in agricultural sciences in the 1960, in Mozambican reality it is not common that undergraduate students publish scientific studies.

Finally, associated with the previous factor, there is reduced number of agricultural researchers in Mozambique. This situation also impacts on the low scientific production on agriculture and maize, in particular. According to Coughlin (2006), it is estimated that until 2006, Mozambique had less than one agricultural researcher for every 50000 inhabitants, against the ratio of 1:2 500 inhabitants in South Africa, Reunion Islands, Mauritius, Libya, Cape Verde, Tunisia, Seychelles and Egypt. 


\section{Mll Macrothink}

Journal of Agricultural Studies

ISSN 2166-0379

2020, Vol. 8, No. 4

From 2011, the number of scientific production increased significantly, reaching eight in 2011 and nine in 2016 and 2017 (Figure 1). In the period between 2011 and 2019, it was published, on average, five studies papers per year. However, we consider that despite the increase observed after 2010, scientific production on maize remains low in Mozambique if one takes into account the relevance of this cereal in the food security and economy of Mozambican rural households. Besides it, maize crop has been chosen as a priority on the national agricultural research agenda (Walker et al. 2006).

The increase of research on maize in the period after 2010 is explained by three factors. Initially, it should be mentioned that in 2004, IIAM began to cooperate with Michigan State University (MSU) of the United States of America ${ }^{1}$. This cooperation allowed the training of Mozambican researchers in the field of agricultural sciences at the postgraduate level (master's and doctorate) at MSU and the sending of researchers of MSU to IIAM. In fact, a significant quantity of agricultural scientific studies in Mozambique is published with authorship and/or co-authorship of researchers from MSU, for example, Cunguara et al. (2013), Uaiene et al. (2009) and Cavane and Donovan (2011).

The second factor is that after 2010, the government of Mozambique has entered into cooperation agreements with other countries that allow higher education lecturers and researchers to obtain scholarships to attend graduate programs in priority areas such as agricultural sciences. This has contributed to increase the quality of agricultural researchers in Mozambique, a situation that can be reflected in increasing of scientific production.

Finally, Sitoe (2014) mentions that the number of IIAM researchers increased from 93 in 2004 to 163 in 2008. The combination of these factors explains, in a way, the increase in scientific production on maize, a situation that has been verified in recent years in Mozambique.

\subsection{Distribution of Studies Based on Region}

The data of the current paper illustrate that about $30 \%$ of the publications cover the entire national territory (Figure 2). The significant existence of studies with a national scope is justified by the fact that maize is the most produced crop in the entire territory, although its importance in food security varies according to the three regions of Mozambique (Mirasse, 2010).

1 Information taken from the MSU website. Available at https://www.canr.msu.edu/afre/projects/mozambique_policy_analysis_and_planning_capacit y_for_improved_food_security 


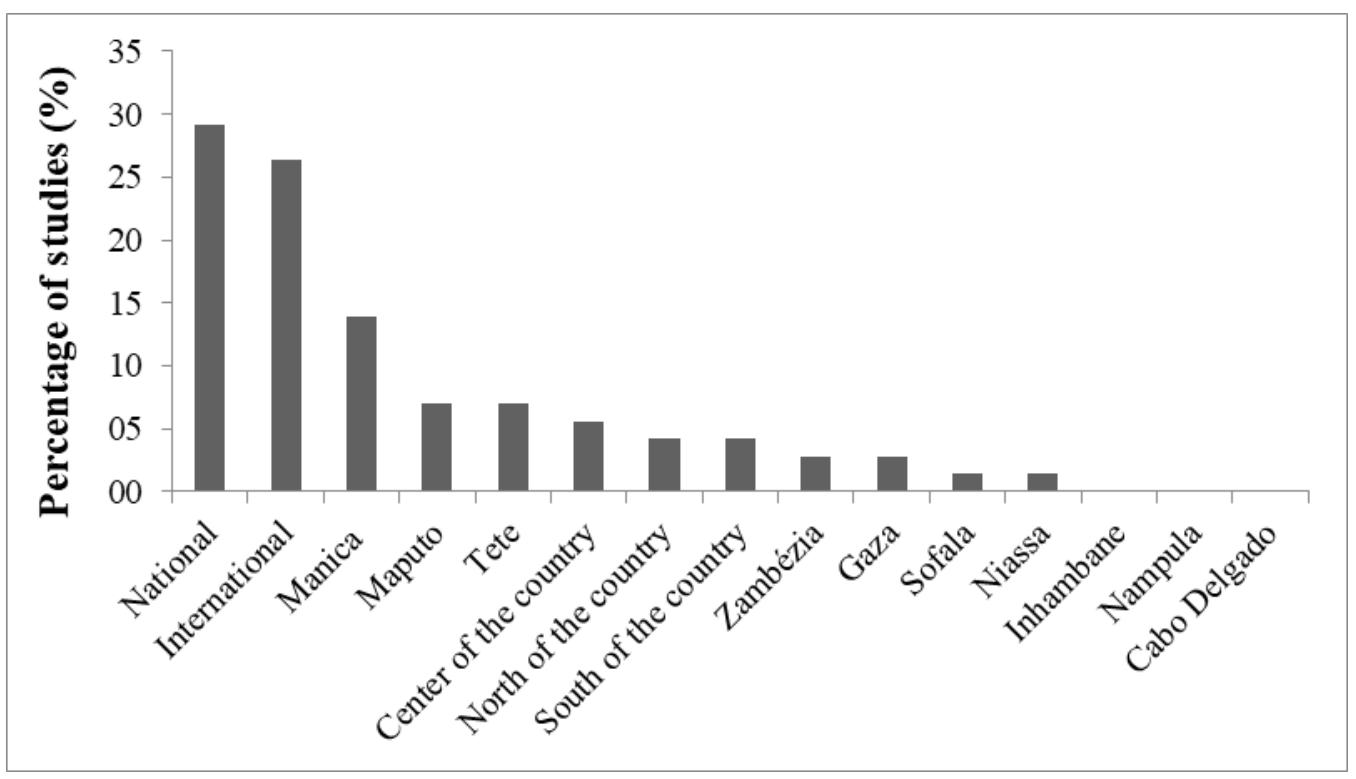

Figure 2. Percentage distribution of studies on maize according to the region covered

Source: Authors. The sum exceeds $100 \%$ because some studies cover more than one region.

Maize is the first crop in terms of cultivated area in Mozambique (MASA, 2015). But its yield is very low compared to its potential (IIAM and FAEF, 2010). This fact can arouse the interest of researchers carrying out scientific studies in order to find solutions to reverse the current scenario. Walker et al. (2006) point out that an increase of $20 \%$ in the yield of maize and cassava reduced the severity of income poverty by $19 \%$, while poverty decreased by about $5 \%$ in 34 of the 80 districts covered by the National Survey on Rural Households ${ }^{2}$. Therefore, the study reveals the relevance of maize research in Mozambique as well as the positive impact that increasing yield has on rural households.

Figure 2 shows that more than $25 \%$ of scientific production on maize cover not only Mozambique, but also other countries. The significant existence of studies with international scope may be associated to the fact that in Southern and Eastern Africa are being implemented several projects aiming to increase agricultural productivity. Most of these projects focus on maize crop, given its relevance to food security and household economies. In 2007, the Bill and Melinda Gates Foundation funded a project to develop drought-tolerant maize varieties (International Maize and Wheat Improvement Center-CIMMYT, 2015). According to the same source, that project was implemented in 13 SSA countries, including Mozambique.

In addition, maize is widely traded among southern African countries. For example, the southern region of Mozambique buys significant quantities of maize imported from South Africa, while the center and north of the country sell the same cereal to neighboring countries, mainly to Malawi (Dias, 2013). The majority of international studies refer to Mozambique

2 This survey was the source used to obtain the data that originated the work of Walker et al. (2006). 
and neighboring countries such as Malawi, Zambia, Zimbabwe, South Africa and E-Swatini (formerly Swaziland).

In terms of the distribution of studies by the provinces of Mozambique, Figure 2 shows that Manica has the majority percentage of publications (14\%) compared to other provinces. Maputo and Tete provinces occupy the second positions in terms of provinces with high number of studies. Therefore, the distribution of studies is largely different across provinces. In addition, this distribution is not consistent with the level of maize production across the provinces. For example, in the 2013/4 agricultural year, the provinces that had most contribution in maize production were Tete with $18.7 \%$, Manica with $15.1 \%$ and Zambézia, with 14.3\% (FEWS NET, 2018). However, Manica province has double of studies of Tete, despite the fact that these two provinces have not very different maize production levels. Maputo province, located in the south of the country, is one with lowest maize production in the country, while Tete is one with highest maize production in Mozambique. For example, in 2015, Maputo contributed with the equivalent of $6 \%$ of the maize produced in the country, while Tete contributed with 21\% (MASA, 2015). Despite this difference in maize production of Tete and Maputo, these two provinces have the same number of studies.

It should be noted that Maputo is the largest maize consumer market in Mozambique. Thus, the interpretation that can be made is that the preference to carry out a significant number of studies in Maputo demonstrates the researchers' concern with generating technologies that contribute to increase maize productivity in this region. This would reduce the dependence of Maputo on markets of central and northern Mozambique, as well as that of South Africa.

Although the northern provinces of Mozambique (Nampula, Cabo Delgado and Niassa) contribute significantly to the national production of maize, the region has few studies on this cereal. In 2015, these provinces contributed with $28 \%$ of the national maize production (MASA, 2015), but only Niassa province has one study. Therefore, the northern region has fewer studies than the south (Maputo, Gaza and Inhambane). In 2015, the south of Mozambique contributed with only $12.8 \%$ of the maize produced in the country (MASA, 2015). This shows that the preference for carrying out studies is not necessarily explained by the productive potential of the provinces, which suggests the existence of other factors that dictate the choice of provinces/regions to carry out studies.

\subsection{Main Themes Addressed on Maize Research in Mozambique}

The results of this study show that $50 \%$ of the research on maize in Mozambique address themes related to agronomic techniques of growing this cereal crop. Maize storage is the less researched theme with only $2.8 \%$ of studies (Figure 3 ). 


\section{$\Lambda$ Macrothink}

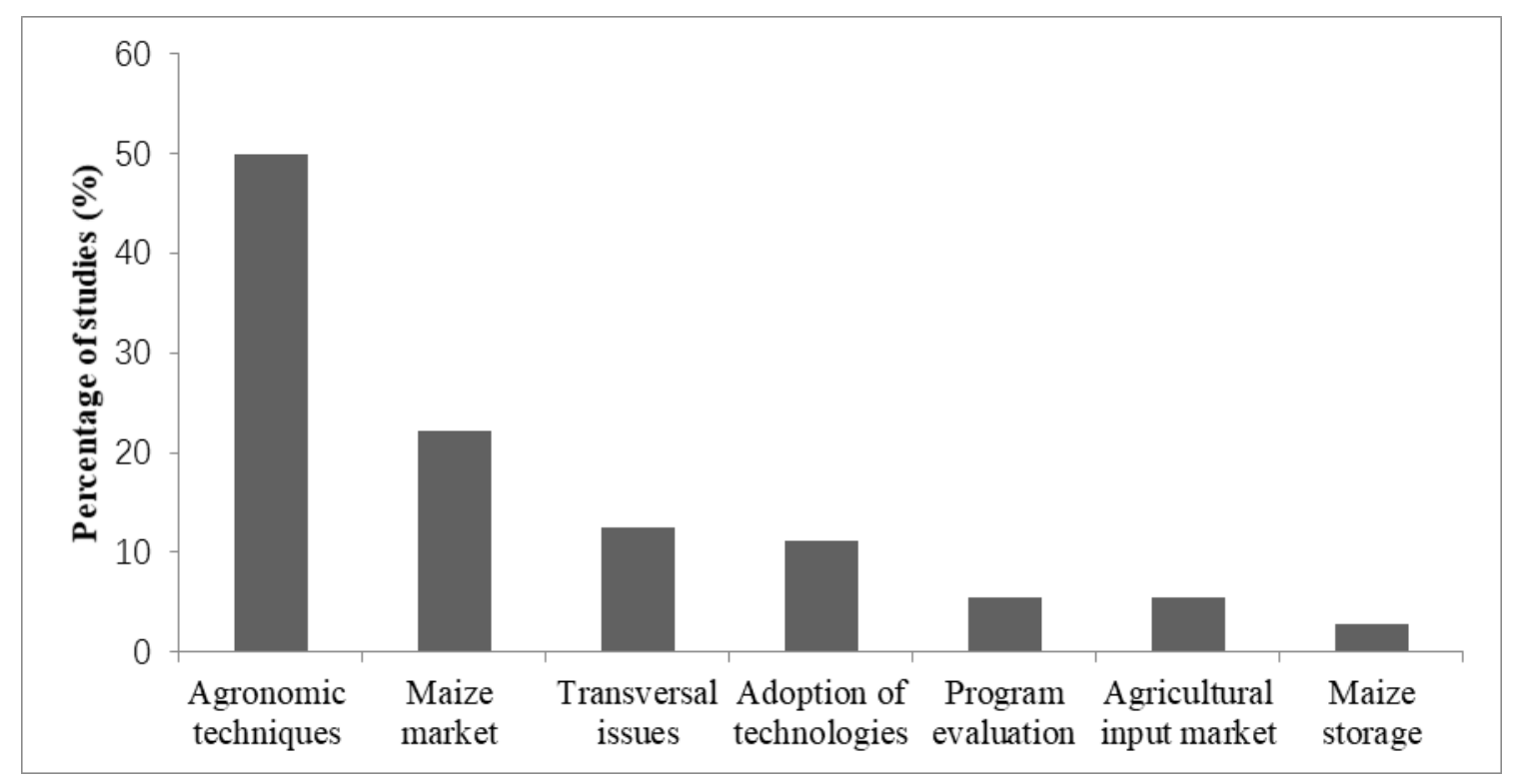

Figure 3. Main themes addressed in studies on maize in Mozambique

Source: Authors. The sum exceeds $100 \%$ because some studies have addressed more than one theme.

The studies that address the agronomic techniques of maize production are distributed between 1988 and 2019, which shows that this theme has always been a concern of agricultural researchers. About half of the studies on this theme are in the north and south of the country. The high interest in conducting research on the agronomic techniques of maize production in the north and south may be associated to the fact that these regions are the ones with the lowest maize yield in the country, which can be interpreted as an attempt of researchers to develop technologies that allow increasing production and maize yield in these two regions.

In relation to specific contents, the studies that address the agronomic techniques of maize growing, tests the effect of factors such as sowing density, intercropping, fertilization, pest control and irrigation on maize yield. The high concern of researchers in carrying out studies on these contents is justified by the fact that maize yield in Mozambique is very low. Roxburgh and Rodriguez (2016) state that a significant number of Mozambican farmers have knowledge gaps in agronomic practices such as sowing dates and sowing density. The authors' estimates indicate that if this problem was corrected, the maize yield would increase by $120 \%$.

In addition to issues related to farmers' knowledge, other factors such as the low use of fertilizers, the low fertility of soils and the lack of pest and disease control are also pointed out as affecting maize yield (Uaiene et al. 2009; Matusso, 2016; Magaia et al. 2016; Davis, 1998). In the utilitarian view of Pinto (2008), it can be argued that these studies are relevant to society because they have the potential to generate technologies that help to solve a concrete problem experienced by maize growers in Mozambique. 
However, Uaiene (2006) stresses the importance of research and rural extension institutions operating in Mozambique in demonstrating the advantages of agricultural technologies, but also the need for them to take into account the profitability of these technologies, as well as agricultural marketing strategies. Therefore, the author makes a connection between technologies and the agricultural market, a problem that is pointed out as a constraint on the development of the agricultural sector in Mozambique

Questions related to the maize market were subject of research in $22 \%$ of the studies (Figure 3). Research on market issues began to be published significantly after 2000. This is associated to the fact that in the early 1990s, the Ministry of Agriculture, through the Agricultural Markets Information System (Sistema de Informação de Mercados Agrários-SIMA), began to publish data of agricultural products' prices in the main domestic markets. In addition, in 1996, the same ministry began to carry out data collection works such as the Agricultural Census (Censo Agropecuário-CAP) and the Agricultural Survey Work (Trabalho do Inquérito Agrícola-TIA). SIMA, CAP and TIA enabled the generation of high volume of data that allowed the production of several scientific works. In fact, 10 of the 16 studies addressing issues related to the maize market are result of data from SIMA or TIA.

Still on the agricultural market, some studies mention that due to market failures, maize production is not always economically profitable for farmers in Mozambique (Tostão and Brorsen, 2005; Mudema et al. 2012). The Mozambican agricultural market has several failures originated by precarious access routes, small-scale production, information asymmetry and inadequate storage infrastructure. These factors tend to increase the cost of agricultural inputs and reduce the price of agricultural products. For example, the precarious state of the main road connecting the South and the rest of the country makes that, at times, the markets of the regions with surplus maize (center and north) are not integrated with the region in deficit, the south of the country. Market failures are one of the problems that hinder the development of the agricultural sector, being associated with low levels of adoption of inputs such as improved seeds and chemical fertilizers.

Some authors argue that being member of farmers association, marketing strategies such as the execution of contracts between farmers and buyers and storage that allows farmers to sell the product when the price is high are crucial for improving the economic performance of maize production (Uaiene, 2006; Zidora et al. 2018).

In our analysis, the improvement in maize production and productivity and the consequent increase in the agricultural income of the farmers' households go through a better structuring of the production chain. This situation can make farmers confident that the increase in production leads to an increase in income.

The factors associated with the adoption of agricultural technologies in the maize farming were studied in $11 \%$ of the works (Figure 3). The main technologies studied were improved maize varieties, chemical fertilizers and conservation agriculture. A recurring issue in studies on agriculture in Mozambique is the prevalence of low levels of technology adoption. For example, in 2013/2014, the adoption of improved maize varieties in Mozambique was around 30\% against almost 100\% in Zimbabwe and Uganda (Abate et al. 2017). 
One aspect to be highlighted is that $12.5 \%$ of the studies analyzed in the current paper capture the perception of farmers about agricultural technologies, with emphasis on improved seeds and conservation agriculture. In some of these studies, farmers demonstrate that they know that agricultural inputs such as fertilizers, improved maize seeds and conservation agriculture technologies allow increasing of maize yields, but the high cost of some of these inputs makes it impossible to acquire them. The perceptions of farmers show that the actions of offering or demonstrating agricultural technologies cannot be dissociated from issues related to the agricultural market, as mentioned by Uaiene (2006), Cunguara and Darnhofer (2011) and Taye (2013).

In order to solve some of the problems of agriculture in Mozambique, the government and some national and international organizations have implemented programs and public policies to support farmers. The evaluation of these programs is analyzed in $5.5 \%$ of the studies. These studies show benefits for farmers with the implementation of some of these programs and policies. For example, Cugala et al. (2006) and Soul-Kifouly et al. (2016) point out that biological control programs for maize pests have benefited farmers, since natural enemies have reduced the populations of maize pests. The program evaluated by Soul-Kifouly et al. (2016) made it possible for farmers from Mozambique, Zambia and Kenya to obtain a surplus of US \$ 1.4 billion.

All studies that evaluated the results of programs mention positive effects on farmers, meaning that they contributed to the household's well-being. However, some of these studies mention actions that have not contributed to the competitiveness of domestic maize production. For example, the food aid for yellow maize that Mozambique received during and after the Civil War (between 1976 and 1992) did not stimulate the national production of this cereal (Tschirley and Santos, 1995). This is due to the fact that the supply of maize has increased considerably in the country, a situation that reduced the price of maize and discouraged Mozambican farmers from growing this cereal for commercial purposes.

Although agricultural input market and post-harvest maize conservation are problems that also negatively affect the agricultural sector in Mozambique, these themes have received little attention from researchers. The $5.5 \%$ of studies that address the agricultural inputs market are related only to improved varieties of maize. Besides being few, these studies do not cover all inputs and production factors, such as the fertilizer, pesticide industry, labor dynamics and animal traction. These are topics that deserve to be studied, since inputs such as fertilizers and pesticides are seldom used by Mozambican farmers.

Post-harvest losses, especially during the storage of cereals and legume grains, are another problem faced by farmers in Mozambique. According to Rembold et al. (2011), between 2003 and 2007, the level of post-harvest losses of maize in the country was about $20 \%$. The study of Popat et al. (2020) points that a post-harvest loss of $3 \%$ of maize produces a direct annual net cost of US \$28 million for both farmers and consumers. Therefore, this is a theme that should be researched widely. According to Sitoe (non dated), the Ministry of Agriculture of Mozambique has implemented projects to control of maize pests in granaries. However, the author points out that many of these projects fail due to the shortage of personnel with 
expertise in granary pest control. This shortage of technicians may be one of the causes of the few number of studies on maize storage in Mozambique.

Regarding transversal themes, such as the environment/sustainable use of natural resources, health and gender, it appears that only environment has been researched in a meaningful way. 8.3\% of scientific production on maize in Mozambique address the issue of conservation agriculture and all were carried out less than 10 years ago. Five of these studies refer to central Mozambique.

The fact that the studies are recent and cover the central region of the country is consistent with the historical context of conservation agriculture in Mozambique. According to Grabowski and Mouzinho (2013), several projects of conservation agriculture have been implemented in central Mozambique. These projects have been subjects of evaluations that generate a significant amount of scientific research. The existence of projects of conservation agriculture is an answer to a question that has been discussed in recent years: the issue of social, economic and environmental sustainability of conventional agriculture. According to Nkala et al. (2011), conservation agriculture provides advantages to the environment and presents better yields than conventional agriculture.

Another recent theme in agricultural research, which was evident in the studies analyzed, is related to climate change. Related to this theme, there are $8.3 \%$ of studies that address issues such as the effect of drought, precipitation patterns and temperature on maize yield. Three of these studies are international. In fact, issues related to the effect of the climate on agriculture are an international concern, especially for less developed countries such as those of SSA (Serdeczny et al. 2017; Cairns et al. 2012). However, if one takes into account that Mozambican's agriculture is widely practiced in dryland, this amount of studies can be considered low. Only two of the studies address the theme of drought in the southern region, which demonstrates a disconnection between this research theme and one of the great problems facing southern Mozambique, the irregularity of rain.

With regard to the other transversal themes, it is worth noting that only one study analyzes the gender issue and one addresses diet and nutrition. Therefore, it appears that although most of those people who practice agriculture in Mozambique are female (Manhiça, 2012) and the prevalence of diseases such as malaria ${ }^{3}$ and HIV-AIDS ${ }^{4}$ is high in the country, there is a lack of studies that analyze these issues. According to Cunguara et al. (2013) and Hawkes and Ruel (2006), the health status of household members influences their productive capacity. Hawkes and Ruel (2006) mention that undernourished and diseases reduces farmers' ability

3 According to Arroz (2016) malaria is the cause of $45 \%$ of external consultations in health facilities in Mozambique. The same author mentions that the prevalence of this disease exceeds $30 \%$ in the central and northern regions of the country.

${ }^{4}$ Regarding HIV-AIDS, UNAIDS estimates that in 2018, 2200000 people were living with this disease in Mozambique and the prevalence rate was $12.6 \%$ among people aged 15 to 49 years. Source: https://www.unaids.org/en/regionscountries/countries/mozambique. Accessed in September, 2019. 
to produce food. In turn, low agricultural production can cause undernourished and low immunity in farmers, making them susceptible to be attacked by various diseases. This is particularly relevant for households that rely mainly on their own production for consumption.

In Mozambican, the time of peak in soil preparation, an activity that demands a lot of physical effort from farmers, which occurs between October and December, coincides with the one with the highest incidence of malaria (Cunguara et al. 2013). Therefore, at that time, a significant part of farmers may be weakened, a situation that reduces their ability to work. Another example of the relationship between health (nutrition) and agriculture in Mozambican households is the fact that the highest rates of malnutrition occur in the provinces where the food production is high. According to INE (2013), in 2013, Zambézia province registered $9 \%$ of cases of acute malnutrition, followed by Sofala, Manica and Nampula with 7\% each. Cabo Delgado and Tete had 6\%, 1\% in Gaza and 2\% in Maputo City. Therefore, the highest rates of malnutrition were registered exactly in the provinces with highest maize production in Mozambique. However, there are few studies that analyze the relationship between transversal themes such as health, gender and maize production. In addition, studies that address transversal themes are more focused on the analysis of technical issues, such as climate change, omitting to analyze other themes of a socio-cultural nature related to maize crop.

\section{Final Considerations}

This paper mapped the agricultural research on maize crop in Mozambique. There is a significant increase in the number of scientific researches on maize. However, given the relevance of this cereal in the food security and in the economy of Mozambicans rural households, this number of studies is still small. It reveals the need of more research on maize in the country, mainly on strategies for adapting to drought in southern Mozambique, since in that region rainfall is more irregular than in the center and north.

Distributing the studies by regions, we found that a significant proportion of the studies covers the entire national territory. There is also a considerable quantity of scientific research that studies maize at the international level. At national level, the distribution of researches across provinces and regions is not consistent with the agricultural productive potential of these regions. Given the lack of clarity on the choice of regions to carry out researches, there is a need to map the regions that need most research on maize, as well as the definition of the main themes to be researched, according to the characteristic problems of each of the regions or provinces of the country.

A considerable proportion of scientific production addresses the theme of agronomic techniques of maize production. This is explained by the low yield of this cereal in the country. However, from the perspective of market-oriented maize production, it appears that this low yield is associated with the fact that agricultural input prices are high, but that of the maize is low. Despite this situation, there are few studies that analyze the market for this crop. This is a contradiction because the practice of an economic activity is based on the behavior of the market. In this sense, researches aimed at generating technologies of high agricultural 
productivity are crucial, but if the market is not favorable, these technologies will hardly be incorporated by farmers. Thus, it is necessary for researchers to carry out more studies related to agricultural market themes so that actions are designed to improve their performance. This has the potential to make the adoption of agricultural technologies profitable and improve farmers' household incomes.

Although post-harvest losses of maize are high in the country, research on this subject is still incipient. This demonstrates the need for further studies on this aspect. However, it also involves training specialists in matters of granary pests, since the number of these professionals is very small in the country.

In recent years, there has been an interest in incorporating some transversal themes in agricultural research, such as conservation agriculture and adaptation strategies to climatic adversities. However, other transversal themes, such as health/nutrition, gender are still addressed in an insignificant way. Thus, further studies are suggested to analyze the relationship between maize and socio-cultural, health and gender themes. Studies analyzing the relationship between nutrition and maize production are particularly pertinent, since the incidence of malnutrition is higher in regions where there is greater production of this cereal. This shows the relevance of social and cultural studies in order to understand the reasons for the high incidence of malnutrition in the provinces with the highest maize production.

Finally, the present paper highlights that the increase of maize production and productivity in Mozambique should be though taking into account the production value chain that might be well organized and structured. This will make maize growers realize the benefits of increasing maize production and yield. Thus, changing the current scenario involves better organization of the market, reduction of information asymmetries, better storage conditions and improvements in access routes.

\section{Acknowledgements}

This research was funded by the Institute of Scholarships (Instituto de Bolsas de Estudo) of the Ministry of Education and Human Development-Mozambique.

We thank Fernanda Machado Ferreira and Thais Helena Teixeira, the editor and anonymous reviewers for their useful comments.

\section{References}

Abate, T. et al. (2017). Characteristics of maize cultivars in Africa: How modern are they and how many do smallholder farmers grow? Agriculture \& Food Security, 6, 1-17. https://doi.org/10.1186/s40066-017-0108-6

Arroz, J. (2016). Aumento dos casos de malária em Moçambique, 2014: epidemia ou novo padrão de endemicidade? Revista de Saúde Pública, 50, 1-7. https://doi.org/10.1590/S1518-8787.2016050006105

Bardin, L. (2011). Análise de conteúdo. São Paulo: Edições, 70.

Byerlee, D., \& Heisey, P. (1996). Past and potential impacts of maize research in sub-Saharan 
$\begin{array}{lllll}\text { Africa: } & \text { a critical } & \text { assessment. Food } & \text { Policy, } & \text { 21, }\end{array}$ https://doi.org/10.1016/0306-9192(95)00076-3

Cairns, J. et al. (2012). Maize production in a changing climate: impacts, adaptation, and mitigation strategies. Advances in agronomy, 114, 1-58. Academic Press.

Cavane, E., \& Donovan, C. (2011). Determinants of adoption of improved maize varieties and chemical fertilizers in Mozambique. Journal of International Agricultural and Extension Education, 18, 5-21. https://doi.org/10.5191/jiaee.2011.18301

Christiaensen, L. (2017). Agriculture in Africa - Telling myths from facts: A synthesis. Food Policy, 67, 1-11. https://doi.org/10.1016/j.foodpol.2017.02.002

CIMMYT, (2015). Nine Seasons of Partnership in Maize Research and Development in Africa: The Legacy of DTMA. A Quarterly Bulletin of the Drought Tolerant Maize for Africa Project, 4 , 1-8. Available in https://repository.cimmyt.org/xmlui/bitstream/handle/10883/4723/570292015\%20v4(4).pdf?s equence $=4 \&$ is Allowed $=\mathrm{y}$

Coughlin, P. (2006). Agricultural intensification in Mozambique: Infrastructure, policy, and institutional framework-when do problems signal opportunities. EconPolicy Research Group Maputo.

Cugala, D. et al. (2006). Assessment of the impact of natural enemies on stemborer infestations and yield loss in maize using selected insecticides in Mozambique. In Annales de la Société entomologique de France, 42, 503-510. https://doi.org/10.1080/00379271.2006.10697485

Cunguara, B. et al. (2013). O Sector Agrário em Moçambique: Análise situacional, constrangimentos e oportunidades para o crescimento agrário. Direcção de Economia, Ministério da Agricultura. Maputo, Mozambique.

Cunguara, B., \& Darnhofer, I. (2011). Assessing the impact of improved agricultural technologies on household income in rural Mozambique. Food Policy, 36, 378-390. https://doi.org/10.1016/j.foodpol.2011.03.002

Davis, G. (1998). A study of the pest status and control of maize stem borers on the Niassa Plateau, Mozambique. International Journal of Pest Management, 44, 225-234. https://doi.org/10.1080/096708798228149

Dias, P. (2013). Analysis of incentives and disincentives for maize in Mozambique. Technical notes series. MAFAP. FAO. Rome.

FEWS NET. (2018). Mozambique Staple Food Market Fundamentals. Available in https://reliefweb.int/report/mozambique/mozambique-staple-food-market-fundamentals-septe mber-2018

Flaherty, K. et al. (2010). Moçambique-Últimos desenvolvimentos na investigação agrária. Maputo: IIAM. 
Freitas, J. et al. (2011). A Teoria de Filière aplicada à cadeia produtiva do milho em assentamento rural no Nordeste do Brasil. VIII Simpósio de Excelência em Gestão e Tecnologia.-SEGeT. 1-12. Available in https://www.aedb.br/seget/arquivos/artigos11/57914732.pdf

Godoy, A. (1995). Pesquisa qualitativa: tipos fundamentais. Revista de Administração de Empresas, 35, 21-29. https://doi.org/10.1590/S0034-75901995000300004

Grabowski, P., \& Mouzinho, B. (2013). Acções de priorização para Agricultura de Conservação em Moçambique. Instituto de Investigação Agrária de Moçambique (IIAM).

Hawkes, C., \& Ruel, M. (2006). Understanding the links between agriculture and health. Agriculture, Food, and Health: Perspectives on a Long Relationship. International Food Policy Research Institute. Available in https://www.springnutrition.org/sites/default/files/understanding_the_linkages_between_agric ulture_and_health-ifpri_2006.pdf.

IIAM and FAEF, (2010). Fichas Técnicas de Culturas. $1^{\text {st }}$ Edition, Maputo.

INE (Bureau National Statistic) (2013). Inquérito Demográfico e de Saúde-2011, Maputo. Available in http://dhsprogram.com/pubs/pdf/FR266/FR266.pdf

Lakatos, E., \& Marconi, A. (2001). Metodologia do trabalho científico: procedimentos básicos, pesquisa bibliográfica, projeto e relatório, publicações e trabalhos científicos.

Magaia, E., et al. (2016). Modelling maize yield response to plant density and water and nitrogen supply in a semi-arid region. Field Crops Research,205, 170-181. https://doi.org/10.1016/j.fcr.2016.12.025

Manhiça, A. (2012). Políticas Agrárias e a Mulher. Seminário do Projecto WARM, 12 de Abril de 2012, Maputo. Available in https://www.fanrpan.org/archive/documents/d01326/WARM_National_Policy_Dialogue_201 2-Politicas_Agrarias_e_a_Mulher.pdf. Acessed in September, 2019

MASA (Ministry of Agriculture and Food Security). (2015). Anuário de Estatísticas Agrárias, Maputo.

Matusso, J. (2016). Growth and Yield Response of Maize (Zea mays L.) to Different Nitrogen Levels in Acid Soils. Journal of Agricultural Science and Research, 4, 35-44. https://doi.org/10.14662/ARJASR2016.069

Mirasse, J. (2010). O consumo de batata-doce de polpa alaranjada entre famílias rurais do nordeste de Moçambique: um estudo sobre percepções de comida e Segurança Alimentar na província de Nampula. Master dissertation. Universidade Federal do Rio Grande do Sul, Porto Alegre, Brazil.

Mudema, J. et al. (2012). Rentabilidade da cultura do milho na zona sul de Moçambique: Estudo de caso do distrito de Boane. Relatório Preliminar de Pesquisa, (3P).

Nkala, P. et al. (2011). The conundrum of conservation agriculture and livelihoods in 
Southern Africa. African Journal of Agricultural Research, 6, 5520-5528. https://doi.org/10.5897/AJAR10.030

Pinto, A. (2008). O Conceito de Tecnologia. São Paulo: Contraponto.

Popat, M. et al. (2020). Postharvest losses at the farm level and its economy-wide costs: the case of the maize sector in Mozambique. Agrekon, 1-20 https://doi.org/10.1080/03031853.2020.1721305

Rembold, F. et al. (2011). The African postharvest losses information system (APHLIS). European Union, Luxembourg.

Roxburgh, C. and Rodriguez, D. (2016). Ex-ante analysis of opportunities for the sustainable intensification of maize production in Mozambique. Agricultural Systems, 142, 9-22. https://doi.org/10.1016/j.agsy.2015.10.010

Serdeczny, O. et al. (2017). Climate change impacts in Sub-Saharan Africa: from physical changes to their social repercussions. Regional Environmental Change, 17, 1585-1600. https://doi.org/10.1007/s10113-015-0910-2

Sitoe, T. (2014). Os desafios da investigação agrária em Moçambique. Desenvolvimento em Questão, 12, 81-104. https://doi.org/10.21527/2237-6453.2014.25.81-104

Sitoe, T. (non dated). On-farm Maize Losses Assessment.

Soul-kifouly, et al. (2016). Assessing the long-term welfare effects of the biological control of cereal stemborer pests in East and Southern Africa: Evidence from Kenya, Mozambique and Zambia. Agriculture, $\quad$ Ecosystems \& Environment, 230, 10-23. https://doi.org/10.1016/j.agee.2016.05.026

Taye, H. (2013). Evaluating the impact of agricultural extension programmes in sub-Saharan Africa: Challenges and prospects. African Evaluation Journal, 1, 1-9. https://doi.org/10.4102/aej.v1i1.19

Tostão, E., \& Brorsen, B. (2005). Spatial price efficiency in Mozambique's post-reform maize markets. Agricultural Economics, 205-214. https://doi.org/10.1111/j.1574-0862.2005.00262.x

Tschirley, D., \& Santos, A. (1995). Who eats yellow maize? Preliminary results of a survey of consumer maize preferences in Maputo, Mozambique (No. 1096-2016-88467).

Uaiene, R. (2006). Introdução de Novas Tecnologias Agrícolas e Estratégias de Comercialização no Centro de Moçambique (No. 1093-2016-87815).

Uaiene. R. et al. (2009). Determinants of agricultural technology adoption in Mozambique. Discussion $\quad$ papers. $67 . \quad$ Disponível em http://cebem.org/cmsfiles/publicaciones/Determinants_of_agricultural_technonolgy_adoption _in_Mozambique.pdf 


\section{Macrothink}

Journal of Agricultural Studies

ISSN 2166-0379 2020, Vol. 8, No. 4

Wakhungu, J. (2010). Gender Dimensions of Science and Technology: African Women in Agriculture. African Centre for Technology Studies Nairobi, Kenya, Presented in Paris.

Walker, T. et al. (2006). Priority Setting for Public-Sector Agricultural Research in Mozambique with the National Agricultural Survey Data (TIA), Research Report Series. Available in http://ageconsearch.umn.edu/bitstream/56113/2/rr_3E.pdf

Zidora, C. et al. (2018). O papel dos contratos e das ações coletivas na produção e comercialização do milho em Moçambique. Revista Brasileira de Planejamento $e$ Desenvolvimento, 7, 461-478. https://doi.org/10.3895/rbpd.v7n4.8745

\section{Copyright Disclaimer}

Copyright for this article is retained by the author(s), with first publication rights granted to the journal.

This is an open-access article distributed under the terms and conditions of the Creative Commons Attribution license (http://creativecommons.org/licenses/by/4.0/). 